\title{
CONTIGUITY OF ISLAM AND LOCAL TRADITION ON THE HINTERLAND MALAYS OF WEST KALIMANTAN
}

\author{
Ibrahim $^{1}$ \\ IAIN Pontianak \\ Email: ab_irhamiy@yahoo.com
}

\begin{abstract}
Islam does not totally reject values and eculture that preceeded over it or previously existed in a given society when it came later to that society. In contrast, Islam gives high respect to local tradition. The presence of Islam actually improves the living order and and good of local culture by means of accomodation, as this is promoted by "Islam Nusantara". The contiguity of Islam and local traditions can be seen in various ways across Indonesia. This article examines such encounter of Islam and local tradition in the Hinterland Malay of West Kalimantan. This study explores and identifes local practices where Islam and local values are blended. This study shows that the tradition of Pantang Larang, Perladangan (buma), Berobat Kampung, and Tepung Tawar reflect unique relationship between Islam and local tradition where these two elements are mutually integrated. Islam does not change such traditions but reshape them. The Islamic propagation (dakwab) is not carried out by erasing local tradition but by integrating itself into the traditions, making a strong structure of mutually-enforcing religion and tradition.
\end{abstract}

Keywords: Islam Nusantara, accommodative, connected values, Islam and local traditions.

DOI: http://dx.doi.org/10.20414/ujis.v22i2.286

\section{Introduction}

THERE ARE TWO MAIN schools/ideologies influencing the culture of people in Nusantara archipelago (referring to islands belonging to Indonesian territory), namely traditions of Islamic and Javanese

1Senior Lecturer on Islamic Communication and Broadcasting and Intercultural Studies, graduated from Doctoral Program of intercultural communication at National University of Malaysia. 
eculture ewith Hindu-Buddhist philosophy. ${ }^{2}$ Indonesian Islam is expression of Islam that mixs its teachings derfrom the Qur'an and Sunna with good local values, and recognized in society. It is sometimes now called as "Islam Nusantara", which refers to Islam which is adapted, learnt and rooted in the culture of the archipelago. Its expression emerges from below, not from Western or Arabic perspective that has different understanding concerning the meaning of archipelago itself. Islam is further confirmed by the wali (Muslim saintsIslamic Saints) and Islamic scholars in the context of the culture of the archipelago. Therefore, Islam Nusantara has unique characteristics of Indonesia, and, in many ways, different from Islam elsewhere, including the Middle East as the origin where it came from. ${ }^{3}$

Islam is responsive and adaptive religion. Responsive means that Islam is not a valueless teaching from the social and cultural context, but it answers or responses the condition of a given community where it emerged. Adaptive means that the Islamic teachings are not static and rigid, but flexible, universal and comprehensive, so that it is able to adapt the changing situation. ${ }^{4}$

As guide and way of life, Islam teaches values in human life, both in the level of relationship to the Creator and the relationship amongst human beings. Islamic teachings are not only about the preparation of life in the Hereafter, but also rather about the necessity of gathering the best provision in this life. Islam exists in the overall values of life and life of Muslim community (umma), whether social, cultural, political, economic, or even religious field. The combination of those values is the underlying religious character currently known as Islam Nusantara.

${ }^{2}$ Adi Fadli, Pemikiran Islam lokal: TGH. M. Shaleh Hambali Bengkel (Lombok: Penerbit Pustaka Lombok, 2016), 1.

${ }^{3}$ See Said Aqiel Siradj, Islam Sumber Inspirasi Budaya Nusantara: Menuju Masyarakat Mutamaddun, ed. A. Khoirul Anam (Jakarta Pusat: LTN NU, 2015), 203-204.

${ }^{4}$ See Sumanto Al Qurtuby, "Southeast Asia: History, Modernity and Relegious Change," Al-Albab 2, no. 2 (November 27, 2015): 145-168, accessed December 26, 2018, http://jurnaliainpontianak.or.id/index.php/alalbab/article/ view/33. 
In other words, Islam with all its teachings based on the Qur'an and Sunna unifies good habits (maslaha) in society and creates a contextual, credible and progressive form of belief system. Such patterns build the characteristics of local form of traditional Islam, such as Nahdlatul Ulama and Nahdlatul Wathan in Lombok. ${ }^{5}$

Islamization of the archipelago accommodates local culture. Islam does not necessarily prohibit wayang (traditional puppet) or other local culture. In contrast, Muslim preachers used local tradition as a medium of spreading the message and teaching of Islam (dakwah). Through dialogue in the puppet story, the wali put important elements of Islam in it. ${ }^{6}$ The same phenomena appear in the other parts of the archiplego such as in West Kalimantan.

Islam entered West Kalimantan and was accepted firstly by rural communities through accommodative and compromistic dakwah approach. As a new religion, it did not prohibit existing local cultural practices, but rather reshaped them. How does such process of dakwah occur in rural communities in West Kalimantan? What characteristics of Islam are found in various local cultural practices and traditions of those communities? How does Islam live and grow along with local cultural practices and traditions of the rural communities of West Kalimantan?

This study thus aims to examine the contiguity of Islam in the expressions of local cultures and traditions that are still practiced by inland Muslim communities in that area. It explores such traditions as pantang larang, buma, pengobatan kampung and topung tawar. This study is continuation of my and my-co-reseracher previous studies of Muslim communities in the hinterland of West Kalimantan. These include the study of Islam and Tradition in

\footnotetext{
5Saparudin, "Salafism, State Recognition and Local Tension: New Trends in Islamic Education in Lombok," Ulumuna 21, no. 1 (June 30, 2017): 81, accessed December 26, 2018, https://ulumuna.or.id/index.php/ujis/article/view/68.

${ }^{6}$ The patterns of Islamic preaching that are very accommodative and compromistic with local cultural practices as performed by the Walis in Java became the main feature of the spread of Islam Nusantara. That is the reason Islam becomes major religion, can grow rapidly and accepted by most Indonesian people nowadays. See Azyumardi Azra, Islam Nusantara: Jaringan Global dan Lokal (Bandung: Mizan, 2002).
} 
Nanga Jajang, ${ }^{7}$ Tradition and Communication in Nanga Jajang, ${ }^{8}$ Communication Wisdom on Pantang Larang of Nanga Jajang of Malay society, ${ }^{9}$ and Wisdom in Buma Tradition. ${ }^{10}$ Additional data were gained from the secondary sources, such as Hermansyah's research report on Magical and Science on society of Ulu Malay. ${ }^{11}$ Furthermore, these materials are corroborated with my observational data and direct experience when visiting and communicating with society in hinterland Malay, especially Nanga Jajang.

\section{The Portrait of the Hinterland Community of Malay}

The society of inland Malay in this study refers to adherents of Islam in the hinterland of West Kalimantan, especially in Hulu Sungai Kapuas (Upper of Kapuas River), commonly known as Kapuas Hulu. Based on the historians' notes, the existence of Malay communities in West Kalimantan, even to inland areas, actually has some interesting stories and is still debatable. One of these issues concerns on the origin of Malay and Islam in West Kalimantan in general, or hinterland of West Kalimantan in particular. Some have stated that Islam and the Islamic community came from Sumatra. Some also argued that Islam was brought to this area directly from Gujarat, India, or Hadramaut, Yemen. ${ }^{12}$ Others maintained that Islam and Malay in Kalimantan are outsiders and never receive a status as indigenous although this

7See Ibrahim, Islam dan Tradisi di Nanga Jajang, Research Report of Competitive Individual lecture (Pontianak: IAIN Pontianak, 2010).

${ }^{8}$ Ibrahim, “Tradisi dan Komunikasi: Studi atas Prosesi Topung Tawar pada Masyarakat Melayu Nanga Jajang," in Tradisi dan Komunikasi Orang Melayu, ed. Ibrahim (Pontianak: STAIN Pontianak Press, 2010).

${ }^{9} \mathrm{Ibrahim}$, Yusriadi, and Zaenuddin, Kearifan Komunikasi dalam Pantang Larang Melayu Nanga Jajang, Kapuas Hulu, Research Report of Competitive Group (Pontianak: IAIN Pontianak, 2009); Ibrahim, Yusriadi, and Zaenuddin, Pantang Larang Melayu Kalimantan Barat (Pontianak: STAIN Pontianak Press, and Malay Corner, 2012).

${ }^{10}$ Ibrahim, "Kearifan dalam Tradisi Buma," in Kearifan Lokal dalam Pemeliharaan Alam (Kalimantan Barat: Fleghty, and PSBMB Kalimantan Barat, 2008).

${ }^{11}$ See Hermansyah, Ilmu Ghaib di Kalimantan Barat (Jakarta: Kepustakaan Populer Gramedia, 2010).

${ }^{12}$ See Azra, Islam Nusantara. 
opinion has no strong historical evidence. A rather interesting opinion come from Victor T. King, who states that the process of spreading Islam through the hinterland was by a conversion process, not migration. Conversion means that Islam comes and is accepted by the local people, who then convert to Islam. They are the ones who finally bore Islamic generations, which today is known as Malay. ${ }^{13}$

What King disclosed is in line with the reality in the field that in fact the Muslim community (Malay) in the hinterland has a clear and close family relationship with non-Muslim community (Dayak). Many of their descendants still have shared kinship, common heritage (tembawang), to the family tree from the same ancestors. ${ }^{14}$

The hinterland Muslim community in this study is the Malay (Muslim) community residing in Ulu Sungai Kapuas which reaches more than $50 \%$, or more than half of the total population in Kapuas Hulu Regency which amounted to 193,616 people. Based on its location, Muslim communities in Kapuas Hulu are scattered across mostly in the coast/upper of Kapuas River (Kapuas) and South Cross Lines. While in the North Track is generally inhabited by non-Muslim community. ${ }^{15}$

From economic side, the Malay people on Kapuas River coast generally work as fishermen. While in the South Cross region they generally specialize in farmland in the rice and rubber fields. This includes the Muslim minority in the North Cross region.

In terms of religious understanding, Muslims in the hinterland generally practice the traditions of ahl al-sunna wa al-jamā'a (Sunni). This background of religious understanding makes the religious

${ }^{13}$ The main idea is King clarifies that hinterland Malay society nowadays is majority of muslim communities who are originally from West Kalimantan that accepts and believes Islam (not migrant from outside of West Kalimantan). See Victor T. King, The People of Borneo (Oxford: Blackwell Publishers, 1993).

${ }^{14}$ See Hermansyah, "Alam orang Melayu: Kajian Ilmu di Embau Kalimantan Barat Indonesia" (Ph.D Dissertation, ATMA, Universiti Kebangsaan Malaysia, 2005). See also in Ibrahim, "Hubungan Penutur Bahasa-bahasa Melayik: kes suku Iban dan Melayu di Badau, Pulau Borneo" (Ph.D Dissertation, ATMA, Universiti Kebangsaan Malaysia, 2013).

${ }^{15}$ See Ibrahim, "Hubungan Penutur Bahasa-bahasa Melayik." 
traditions grow and develop well in the social practice of religious community. ${ }^{16}$ This factor finally generates various forms of tradition that still exist and is practiced in society, such as pantang larang (taboo), pengobatan kampong (traditional healing), and topong tawar (tasteless flour or special flour).

\section{Islam and Local Tradition of Nusantara}

Since Islam Nusantara commonly embraces the school of theology of ahl al-sunna wa al-jamā'a, traditional Islamic practices can be found in many aspects of religious life of the Nusantara Islam. This feature is not only found in the geographical region of the archipelago but goes beyond the geographical borders. It has the same historical roots as in Surinam-Holland, where the slametan tradition becomes a cultural identity of Javanese Muslims with moderate Muslims. ${ }^{17}$

In Bima in the island of Sumbawa, West Nusa Tenggara, for example, Islamic identity and agency is established through ritual and pest practices. Muslim of Bima considers that their religious, political and cultural practices are Islamically-based tradition. They interpret that their Islam is a response to their surroundings; therefore, the complexity of religious life called as the result of the duality of socio-political arrangements in Bima started from the early period of Islamization of Bima to the present time. ${ }^{18}$

Such characteristic of Islam Nusantara is also found in the Muslim community of Cirebon, West Java, where Islam and tradition live side by side and align in religious practice of society. There are many customs that actually stemming from non-Islamic cultures, but are tolerated and modified, so that they no longer

${ }^{16} \mathrm{Ibrahim}$, "Islam and Tradition in Nanga Jajang: Social and Religious Practices Of the Malay Community," Al-Albab 4, no. 2 (December 1, 2015): 217229, accessed December 26, 2018, http://jurnaliainpontianak.or.id/index.php/ alalbab/article/view/290. See also Ibrahim, Islam dan Tradisi di Nanga Jajang.

${ }^{17}$ See Moh Khusen, "Contending Identity In The Islamic Ritual: The Slametan among Surinamese Javanese Muslims in The Netherlands," Al-Jami'ah: Journal of Islamic Studies 43, no. 2 (November 30, 2005): 283-308, accessed December 26, 2018, http://www.aljamiah.or.id/index.php/AJIS/article/view/42.

${ }^{18}$ Muhammad Adlin Sila, "Menjadi Muslim di Bima Sumbawa Indonesia: Keanekaragaman Politik dan Budaya" (Doctoral Thesis, Australian National University, 2014). 
break the principles of faith in Islam. In practice, the customary rituals of Islamic holy days, slametan, until the festival of harvest becomes a means of expressing their Islamic identity. ${ }^{19}$

Likewise in the hinterland of West Kalimantan, which is generally adherents of Sunni Muslim and followers of the Shafi'i Islamic law school, ${ }^{20}$ the influence of Islam in cultural practices and traditions is strong. Islam becomes an integral part of existing cultural practices and traditions. Traditions and cultures practiced by society reflect the existence of Islamic values in that society.

In the Islamic discourse, tradition becomes an integral part of the social life of society, including some religious ritual practices. Even in many instances, traditions and religious rituals are not easily separated. What refer to the basic meaning of tradition are the habits undertaken by a society, derived from social and cultural practices and are inherited from generations to generations. While Islamic religious rituals are practices based on the Qur'an and Sunnah that serve as a medium to worship and communicate to God. ${ }^{21}$

An example of a combination of traditions and religious orders exist in the religious rituals of today's society, such as the traditional healing (berobat kampung). In the context of this tradition, Islam only commands the followers not to be easily despaired of Allah's grace and help when they fall ill. Even the

${ }^{19}$ See Abdul Ghafur Muhaimin, “The Islamic Traditions of Cirebon” (Ph.D Dissertation, Australian National University, 2006), espepcially on the chapter of the Ritual Practice: Adat, 115-158.

${ }^{20}$ Hermansyah, "Islam Orang Embau," in Islam dan Etnisitas di Kalimantan Barat, ed. Yusriadi and Ambaryani (Pontianak: STAIN Pontianak Press, 2008).

${ }^{21}$ Regarding to contiguity of Islam and Tradition in faith and lives' practices of hinterland society, at least there are three common patterns found, they are: firstly tradition of acts descendantly to generations; secondly; syncretic or a traditional practice influenced or colored by Islamic values; thirdly; changing or pure Islam where the abrogation of local tradition practices exists and replace them with pure Islam. See Hermansyah, "Islam dan Budaya Lokal (Islamisasi Budaya Masyarakat Pedalaman Kalimantan Barat)," in Dakwah Islam di Kalimantan Barat, by Yusriadi and Patmawati (Pontianak: STAIN Pontianak Press, 2006). In this studies, tradition in society seen as the combination of three common patterns, they are local tradition, consists of Islamic elements (values) in it, and the changing of tradition practice which are compromise and accommodative. 
Qur'an gives assurance that the disease is from Allah, but $\mathrm{He}$ creates the medicine to heal it (Q.S. 26: 80). ${ }^{22}$ Therefore, human beings are asked to pray only to Him (Q.S. 2: 186). ${ }^{23}$ However, the practice of healing (berobat kampung) todays shows various forms of implementation of Islamic tenets, indicating the presence of Islamic contacts with local traditions within the hinterland Muslim community. Likewise, the traditions of pantang larang, land cultivation (huma) and topung tawar, reveal the presence and mutual contact of Islam and traditions in Muslim communities there.

\section{Contiguity of Islam and Local Tradition}

\section{The Tradition of Pantang Larang}

Pantang larang (abstinence, taboo or prohibition) is a well known tradition in the life of Malay people of West Kalimantan. Many aspects of people's lives are mirrored in the pantang larang, from life in the family (household), social life, economic and social activities, marriage and birth, to those associated with death, ${ }^{24}$ and harvest time. ${ }^{25}$ Elements of Islam blend within this tradition. Not only on the verbal expression but also on the content of the tradition does Islam arise. In principle, the pantang larang is a communication strategy built by parents to provide teaching and education to their children and generation. ${ }^{26}$ Below are four examples of the pantang larang expressions that intersect with Islamic values.

${ }^{22}$ “When I am ill, He (God) heals me” (Q.S. Asy-Syu `ara: 80).

23 "And when My servants ask you Muhammad about Me, then (let them know that) I am very close (to them). I grant those who ask Me. They should obey My command and believe to Me so they will gain truth (Q.S. Al-Baqarah: 186). See M. Quraish Shihab, Tafsir Al-Misbah, vol. 1 (Jakarta: Lentera Hati, 2004).

${ }^{24} \mathrm{Ibrahim}$, Yusriadi, and Zaenuddin, Pantang Larang Melayu Kalimantan Barat.

${ }^{25}$ Compare to James T. Collins, "Bahasa Pantang Larang di Pulau Tioman: Refleksifikasi Semasa Menuai"," Jurnal Dewan Bahasa 36 (1992): 916-933.

${ }^{26}$ Ibrahim, "Pantang Larang dan Pengajaran Keseimbangan Hidup," in Prosiding Koloqium Internasional Khazanah Pendidikan di Alam Melayu (presented at the Koloqium Internasional, in Colaboration Pascasarjana STAIN Pontianak and ATMA Universiti Kebangsaan Malaysia, Pontianak: STAIN Pontianak Press, 2014), 55-76. 
The first example here deals with the ettique of visiting graveyard. For example, it is strongly discouraged to cry at the graveyard because it may add torture of the dead. Visitors should not sit on the tomb, nor step on it. Moreover, menstruating woman should not come along to the grave, because they are impure.

These are the pantang larang ethical values of living people to the dead, which strongly relate to Islamic teachings. Crying (or wailing) over the grave is strictly prohibited in Islam, as explained by the Prophet's Tradition narrated by Bukhari. ${ }^{27}$

Likewise, concnerning the burial place (grave), Islam teaches its followers who are still alive to honor the tomb as the advice of honoring the dead bodies buried beneath it. Sitting or walking on the tomb can be interpreted as impolite or disrespectful to the deceased. Therefore, Islam forbids the behavior of sitting on the tomb or even stepping over it.

A similar meaning can also be understood in the prohibition of menstruating women to visit the grave. Menstruation is symbolized as impure that barr women from making worship such as prayer or reciting the Qur'an. On the other hand, the grave is the place where every body will meet their Lord after leaving the world, and hence it is considered holy place. Therefore, the tomb should not be contaminated by the female's blood of menstruation.

The second example relates to the ettique with the scriptural texts (the Qur'an) and prayer. There a number of attitudes considered to be improper in dealing with the Qur'an and prayer. For example, one must not step over the Qur'an. One cannot also pass through in front of praying person.

Such pantang larang values are clearly influenced by Islam, where the respect of the Qur'an as a holy book must be upheld. One must be also pure when touching the Qur'an. Islam teaches many ethics related to the Qur'an. It is, for example, highly recommended to put the Qur'an in a cleaner and higher place, grab it with the right hand, and uphold and kiss it before opening

27 This Hadits specifically explains the Prophet's prohibition on pre-Islamic Arabic culture that cried over to their dead family till moan. Moreover they scratch their faces as they did not accept it. 
and reciting it. These values also may influence the initial of pantang larang in society of hinterland Malay related to the existence of the Qur'an.

Similar messages are also seen in the need to respect people who are performing obligatory daily prayers. Prayer is the most important worship in Islam because it is the pillar of religion and the first Islamic observance to be audited in the afterlife. According to the Prophetic tradition, those whose prayer is perfect, then all his/her worship will also be considered perfect. It is therefore understandable if prayer stands an important position in Islam. Muslim society in the world has a distinct way in realizing this principle. In West Kalimantan, the pantang larang partly reflects such teaching when it is concerned with the Qur'an and prayer. The Malays' attitude of the hinterland in this region to the Qur'an and prayer is strongly shaped by the Islamic doctrines.

Next, keeping the sight on things that are not justified is a strong command in Islam, moreover to one's aurat. The eye is a valuable gift from God to humans, but when they are unable to lower their gaze, this may cause a divine curse. To actualize this message, pantang larang made in the term of a threat of tumbir (swelling/nodule) for those who see somebody's concealed part of the body (aurat).

The third example relate to ettique in dealing with entering home or area and building toilet. The pantang larang maintains that if one starts stepping, he/she has to begin with the right foot, not the left one. Likewise, if one enter a place such as football arena, one need to use his/her right foot first to enter into it. The tradition further states that a toilet in a building must not face to Qibla (a sacred house of God in Mecca where Muslims direct their face when praying). Toilet construction must face to either north or south.

Starting good thing with the right side (foot or hand) is a virtue in Islam. Even the Prophet has referred to this as the recommended act (Sunna). Islamic teachings signal the right side as a symbol for kindness (good values), which therefore good work must also begin with the right side. On the contrary, the left side symbolizes as defilement, hence dirty duty is recommended to be done by the left hand. 
In line with the message of virtue to the right for good things, and instead left for dirty things, the teachings of Islam also prohibit building toilet that face or back to the Qibla. Toilet is a place of sewage, and Qibla is a holy place that becomes the direction of every Muslim in performing their prayer.

The forth example of the pantang larang where the local practice has been influenced by an element of Islamic doctrines is concerned with the prohibition to wash or seep on Friday night since it may interrupt the flow of livelihood. It is not advised for somebody to sleep before the evening (maghrīb) because he/she may be possessed by evil spirit. The same advice is given to close the window to avoid being possessed by spirit before maghrïb and after $i s h \bar{a}^{\prime}$.

In one tradition, it is said that Friday is the best day for Muslims. The hadith describes the privilege of Friday, the day where adult male Muslims are required to perform Friday prayers together at mosque. This obligation is firmly found in Q.S. 63: 9-11. Managing the job well while ensuring attendance of the Friday prayer constitutes a religious order. Hence doing a job that can ignore the obligation of the prayer, or ignore the meaning of the Friday prayer virtue (sayyid al-ayyām) is considered futile, that may hamper the livelihood (rezeki).

The other expression reminds that humans mostly experience losses, except those who believe and do good deeds, and remind each other (Q.S. 103: 1-3). Among the time passed by humans in life is the turn of the day into the night (time of maghrīb). In this interregnum time from light to darkness there are at least two important meanings in the teachings of Islam; first, the obligation to perform maghrib prayers; second, the turn of the day and the night life into the night. In this case, the teachings of Islam also recognize that besides humans, this universe is also inhabited by other creatures that are invisible, and night is the time for them.

The Prophet explains that the most favored period by the devil is in the turn of the day into the night (maghrib). At that time the genies and demons come out, looking for food and life. According to the tradition, these creatures actually consume what people eat if they do not recite bismillăh when start eating. Even, the demons 
will stay at home and remain in the dirty (unclean) human body when entering the night time.

The pantang larang related to the time of maghrīb and isha' (turnover of day to night), as the other expressions regarding graveyard visit, prayer, the Quran, is influenced by Islamic values that the hinterland Muslim community understand and include this into the category of taboo or abstinence that must be evaded.

\section{Farming Traditions (Buma)}

As an agricultural society, farming (buma) is the main occupation of the people in West Kalimantan, especially the hinterland Muslim community, both in the form of wetlands (rice fields) and dry land (unirrigated fields). As the geographical condition of coastal areas is closer to the sea-river, the more dominant activity is agricultural of wetlands (rice fields). In contrast, in the hinterland areas far from the sea-river surface, the activity of cultivation is generally on dry land (huma-fields).

Land cultivation (buma) is routine work for the hinterland Malay society to sustain the needs of family's life. ${ }^{28}$ Not only do the Malay work in farmland, but almost all ethnic communities in the hinterland such as Iban, ${ }^{29}$ Kantuk, $^{30}$ Buyan Malay, ${ }^{31}$ and Muslim Dayak also do the similar work. ${ }^{32}$

As an annual routine, the activity of cultivation (buma) for hinterland communities is an important tradition. The arrival of Islam provides a clear touch and influence in the practice of farming traditions. This is seen at the various provisions 91.

${ }^{28}$ Ibrahim, Hidup dan Komunikasi (Pontianak: STAIN Pontianak Press, 2010),

${ }^{29}$ Reed L. Wadley, "Circular Labor Migrations and Subsistence Agriculture: A Case of The Iban in West Kalimantan, Indonesia" (Ph.D Dissertation, Arizona State University, 1997).

${ }^{30}$ See the article of M.R. Dove, Swidden Agriculture in Indonesia. The Subsistence Strategies of the Kalimantan Kantu (Berlin, New York, \& Amsterdam: Mouton Publisher, 1985).

${ }^{31}$ Didi Darmadi, “Bung dan Bami' Ari: Budaya orang Melayu Buyan," Harian Equator, March 17, 2006.

${ }^{32}$ Faizal Amin, "Kitab Berladang: A Portrait of Hybrid Islam in West Kalimantan," Studia Islamika 20, no. 1 (2013): 59-96, accessed December 26, 2018, http://journal.uinjkt.ac.id/index.php/studia-islamika/article/view/349. 
concerning the stages and procession of work, starting from ngabas tanah, $^{33}$ planting rice in mpalang bonih, ${ }^{34}$ to cultivating rice and caring for it from disease. ${ }^{35}$

Ngabas tanah is the first activity to farm. At that time, all natural cues (such as the sound of birds) were taken into account to determine the quality of the soil. ${ }^{36}$ In the book of land cultivation, it is stated that when doing ngabas tanah one should recite several sura (chapter of the Qur'an) such as al-Ikhlas, al-Falaq, al-Nas and al-Fatiha respectively seven times. One should then greet the Prophet Ilyas as permission to cultivate the land. After that, one may start working on it. ${ }^{37}$

When the land is clean and ready to be planted, the next procession is to make mpalang bonih. Mpalang bonih resembles the star ( 3 to 9 plots of stars), and is made in the middle of the field of cultivation (huma). Then, the seeds are planted firstly in the star plot. ${ }^{38}$ One should recite a prayer when start planting, shouting "Kun Jada Jadi ah Jadi, Berkat Doa La Ilaha Illa Allah Muhammadun Rasulullah."39 The prayer is in local language but it contains Arabic, where farmers asking the blessing of Allah and the Prophet Muhammad for their plantation. Likewise, when the rice is planted on the soil, one is advised to recite bismillah al-rahman alrahim. Man talabatanwaal jada wal jaddi kawan ahjadi-jadi nur Hayat Allah. ${ }^{40}$

\footnotetext{
${ }^{33}$ Ibrahim, "Kearifan dalam Tradisi Buma"; Darmadi, "Bung dan Bami' Ari: Budaya orang Melayu Buyan."

${ }^{34}$ Hermansyah, "Alam orang Melayu."

${ }^{35}$ Amin, "Kitab Berladang," 59-96.

${ }^{36} \mathrm{Ibrahim}$, "Kearifan dalam Tradisi Buma"; Ibrahim, Hidup dan Komunikasi.

${ }^{37}$ Amin, "Kitab Berladang," 59-96.

${ }^{38}$ Hermansyah, "Alam orang Melayu."

39 This lapaz is not in the actual Arabic meaning. but rather is a mixture of local and Islamic meanings, which are related to prayer or mantra when sowing rice (padi) seeds in the farming season (buma). Therefore the sentence is more meaningful as follows; so then this rice (padi) grows and bears fruit. thanks to prayer la ilaha illallah Muhammadun Rasulullah. According to Faizal Amin, this phrase shows how the process of mixed culture has resulted in the establishment of prayer readings in Arabic that also contain mantra. See Amin, "Kitab Berladang, 2013: 79-80"

${ }^{40}$ In part of the sentence above, this lafadz is also more a mantra with the meaning of contact with local and Islamic culture. Therefore, the lafaz is
} 
The description above shows that the contiguity of Islam is clearly visible in every stage of the agricultural procession amongst the hinterland Muslim community although Islam came later when the practice of cultivation had established. The presence of Islam does not necessarily eliminate all forms of the local tradition and practices, but reshape them. This can be seen from the content of the prayer. The tradition of land cultivation and planting remain the same, but the content changes where a prayer with Islamic invocation is inserted. This also includes refinements in work processions of equal worth, silaturrahmi (mutual visit) and help, as in "bung", "bami ari" or "mun".

"Bung" is a tradition of working in the fields (buma) collectively. Typically, people who are helped with this "bung" tradition are community leaders, religious figures, or figures as role models in the society. In this "bung" tradition, the owner of the field only provides enough food for the workers. People are eager to work to help sincerely without asking for compensation (salary). "Bung" in the tradition of farming (buma) is still carried out by many Malay villages in the hinterland of Kapuas Hulu, including in Boyan. ${ }^{41}$

Besides "bung", they also practice "Bami ari" or "Mun". This tradition is slightly different from "bung". If the tradition of "bung" is done in the form of cooperation and does not require rewards or replies, "bami ari" or "mun" is vice versa. "Bami ari" in the local term means "taking days" in the form of acceptable accounts, for people who have taken the day are obliged to repay the same number of days to help those who have worked to help them. Because the nature of mutual help between them, the people involved in the tradition of "bami ari" are also certain in number, so in the process of replying (work) is clearly accounted. Working system is done by mutual cooperation and the work of fellow members. This tradition is also known as "Mun", which in local terms means "berambi gang".

meaningful; In the name of Allah who is all-loving and merciful. Who asks for this rice to be made, then it becomes fruitful. Friends become and bear fruit with the light of God. See Amin, "Kitab Berladang, 2013: 79-80"

${ }^{41}$ Darmadi, "Bung dan Bami' Ari: Budaya orang Melayu Buyan." 
"Bung", "bami ari" or "mun" also lay down the obligation to prepare meals by landowners or farmers for workres who assist them. The difference is that the "bung" is a pure help and mutual assistance or without requiring the same reward. Meanwhile "Bami ari" or "mun" requires a similar exchange of workload if another member needs help someday.

The process of shifting cultivation (huma) reinforces the value of Islam in the practice of the buma tradition of hinterland Malay society, such as the values of cooperation and mutual help in "bung" as implied the Qur'an 5: 2, a practice of helping to build togetherness and silaturrahmi among village fellows.

\section{Traditional Healing}

There is a modification process to the transformation of Islam in people's lives manifested very clearly in the tradition of traditional healing. This fact shows that Islam is able to play an important role in the social and cultural system of hinterland Muslim society, both in adaptive and transformative forms.

In adaptive form, Islam does not immediately change or ban all existing local traditions, including traditional healing. It come along with the preservation of healing tradition in local society. In this way, society does not look at Islam as a new life provision that denies all traditions they have done in the social and cultural history of their ancestors. Adaptive ability of Islam on the tradition of traditional healing and culture of the people in the hinterland has commonality with the preaching approach in most of the archipelago, especially in Java. The nine saints' (Wali Songo) method of spreading Islam in Java utilized the leather puppet as a medium in conveying the message of their dakwah. ${ }^{42}$

Through cultural approach, Islam is slowly able to give a colorful contiguity in the procession and verbal expression (mantra-jampi) of the traditional healing. Some examples below show the existence of Islamic elements in the invocation of the healing, either at the end (example 1), at the beginning and at the end (example 2) or at the whole (example 3). The transformation

\footnotetext{
${ }^{42}$ See the detail on Azra, Islam Nusantara.
} 
can be traced back by comparing the original invocation of the healing with the one that has become Islamic (example 4).

\author{
Tawar Ular (Example 1) \\ Urat pusat mamang kunin \\ Raja mungkar dalam tanah \\ Menyengkung seperti akar \\ Berdiri seperti kayu \\ Mati yang kunin \\ Idup yang putih \\ Tabar bisa nait tawar \\ Berkat doa la ila ha illallah \\ Berkat muhammad rasulullah ${ }^{43}$
}

The examples above show that in general, the invocation (lafaz) treatment of the traditional healing is still very local derived from traditional poetry's phrase. One sentence with the next sentence is related to the similarity of the word rhythm and the term, so the art's nuances feel in the Malay tradition. When the influence of Islam takes place, then lafaz is given a closing sentence with the characteristic of Islamic creed.

This is done not only as an effort to preserve the existing tradition and not contrary to the values of Islamic teachings, but to increase confidence in the power of traditional healing for Malay people today, where the power of Allah becomes the ultimate determinant for healing endeavors through the healing tradition.

The role of Islam in the tradition of traditional healing is also clearer when accommodation and value transformation are not only at the end of lafaz as in Example 1 above, but in the beginning (opening) and at the end (closing), as in the following example:

Tawar Asal Tekonak (Example 2):

Bis millahirrahmanirrahim

Cuka apa cuka itu

Cuka ada dalam pasu

Luka apa luka itu

Luka pantap utan semolih antu

Berkat doa la ila ha illallah

Berkat muhammad rasulullah ${ }^{44}$

${ }^{43}$ Hermansyah, Ilmu Ghaib di Kalimantan Barat, 151.

${ }^{44}$ Ibid., 154. 
The above example shows a tradition that begins by reciting the name of Allah (as values commonly taught in Islam), and ends by the creed. This really shows the accommodative characteristic of Islam to the traditions of local healing. The essence of lafaz of prayer is preserved as its mid-sentence, with distinctive language style, poetic nuance, poetry and traditional poetry.

In addition, the highest of Islamic touching in accommodating the tradition of traditional healing and the transformation of Islamic teachings appears in Example 3, where the changes (modification and transformation) are not only at the beginning and end of lafaz, but it shows the Islamic teachings clearly, as the following example:

Do`a Pelias berjalan (Example 3):

Allah payung $\mathrm{ku}$

Jibril kota $k u$

Malaikat empat puluh empat pagar $k u$

Aku berjalan dengan kuasa Allah

Aku melenggang dengan lenggang Muhammad

Bukan kata ku, kata Allah

Berkat do`a la ilaha illallah

Berkat Muhammadurrasulullah ${ }^{45}$

The above example shows an attitude of complete submission (totality) to the will of Allah, an attitude which surrenders all (health and salvation) only to Allah. However, the style of language is generally still the same (similar), ending with the blessing of the creed (Shahāda).

The examples above $(1,2,3)$ in contact with Islam (both accommodative and transformative) are very clear from the lafaz of original traditional healing (without Islamic values), as the following example:

Lafaz Tawar Perdora' (Example 4):

Mpurung sibang sibu

${ }^{45}$ This is an oral tradition from Nanga Jajang. The informant generally admitted that the reading was taught by Ustadz Shaleh Kamaruddin (alm), a religious leader who was considered to have an important role in the education and propagation of Islam at the Ulu Kapuas at that time. See Ibrahim "Islam and Tradition in Nanga Jajang: Social and Religious Practices of the Malay Community." Al-Albab 4, no. 2 (December 1, 2015): 217-229. 
Ngelayang batang kepuas

Puki inai ikau bebulu

Butuh apang ikau pulas ${ }^{46}$

In the form of meaning, the lafaz above does not have a clear relationship with the treatment and healing process of an illness. Even in the language of the local community, lafaz connotes to obscene and indecent meanings. However, in terms of language style, it has similarities with lafaz of traditional healing in general, with the art of old poetry like in the previous example.

\section{Tradition of Topung Tawar}

Topung tawar is one of the traditions that still exist in the living culture of hinterland Muslim communities of West Kalimantan. This is concerned with the seventh month of pregnancy (nujuh bulan), cutting baby's hair, circumcision (sunatan), marriage, building new house, buying new vehicle and so on. ${ }^{47}$ In Sambas, topung tawar becomes the main tradition of safety ceremonies, whether to welcome the birth of a baby, pregnant women, haircut, circumcision (sunatan) and others. They often call it as "tepung tawar" 48 .

One of the values of Islam referred in this local tradition is concerned with the beginning of the ceremony where it begins with reciting basmalah and al-fätihah and ends with șalāwat to the Prophet. Even in some of its processes, lafaz of prayers in ceremonies also use the verses of the Qur'an or prayer of selamatan while wagging water of flour and other ceremonial completeness.

However, the general lafaz which is recited in a topung tawar ceremony is in the form of a rhyme or rhyme rhythm that has the same word or sentence as follows:

Do`a Topung tawar:

bismillahirrahmanirrahim

topung tawar si topung jati,

${ }^{46}$ Hermansyah, Ilmu Ghaib di Kalimantan Barat, 153.

${ }^{47}$ Ibrahim, "Tradisi dan Komunikasi."

${ }^{48}$ Erwin and Andi Gidang, “Tradisi yang Membelajarkan: Mengurai Unsurunsur Pendidikan dalam Tradisi Tepung Tawar Melayu Sambas," in Tradisi dan Komunikasi Orang Melayu, ed. Ibrahim (Pontianak: STAIN Pontianak Press, 2010), 205-226. 
topung asal mula menjadi, amay-amay pucuk mali-mali limau purut si limau lelang tegak dengan limau melaka air surut penyakit ilang tegak dengan sial celaka ${ }^{49}$

The lafaz of this prayer is read out simultaneously with the ceremony of splashing the topung tawar's water to the person who is prayed for. This water is actually taken from plain water, put together with (powder-juice) flour to be whitish colored and called water of topung tawar. Tawar in the context of this ceremony has some meanings. First, it means no taste (not sweet, salty, or

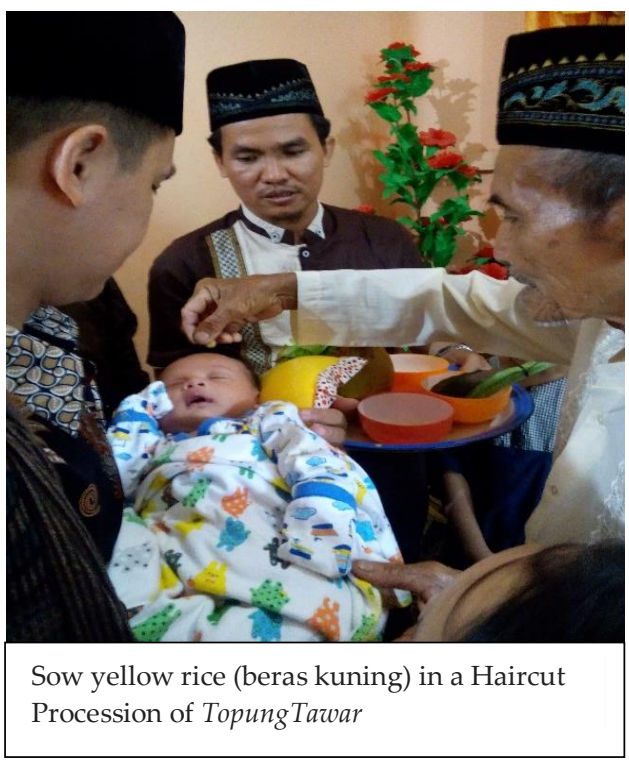
sour). Second, it uses plain water that has been blessed by prayer to heal or eliminate disease. ${ }^{50}$

The ceremony procession of topung tawar is followed by reading the following lafaz:

Kuu.. semongat rezeki murah

apa dicinta lalu ada

apa diniat lalu didapat

manis muka senang hati ${ }^{51}$

The lafaz of this prayer is read out simultaneously with the ceremony of sowing yellow rice to the person prayed for. Usually the rice is sown to the forehead of the head, chest, shoulders up to both hands, and the last leg of the prayed person. Even in some ceremonies, the yellow rice is also sown to the area around the

\footnotetext{
${ }^{49}$ Interview with Uju Unui (Unui Salim), November 2009

${ }^{50}$ Ibrahim, "Tradisi dan Komunikasi."

${ }^{51}$ Source: Uju Unui (Unui Salim), Intervieu Nov. 2009
} 
ceremony, which could be about the people who participated in the ceremony.

As topung tawar's water, this yellow rice also includes the main ingredient in traditional flour ceremonies, made from rice and turmeric juice, making it yellow and called yellow rice. ${ }^{52}$ For the Malay community, yellow rice is believed to be a symbol of the strength and brilliance of Malay society.

The last part of this tradition's ceremony is when the pini sepuh (ceremonial senior performer) recite the following prayer:

kuu... semongat

korin bosi korin semongat

panyang aik panyang penyawak

tinggi tayak tinggi tuah

baka tanah na tau susur

baka batu na tau pupur ${ }^{53}$

While reading the lafaz, the performer of the ceremony thrust a piece of iron (usually in the form of a kitchen knife) to the mouth of the person who was prayed for and then smacked or bitten with the lips. The basic meaning of this tradition is an attempt to generate strong self-spirits in people who pray as strong and hard as iron. Another meaning, of course, the strength of spirit and belief in the ability of self is very influential for one's life. Here is one meaning of effort in life, which by that end people may be able to provide a better change for themselves and their people, referring to the Qur'an in Sura al-Ra'du: 11, as a manifestation of the value (contact) of Islam in the ceremony of the topung tawar.

\section{Conclusion}

The intersection and integration of Islamic teachings with local customs is manifested through various traditions of Nusantara Islam, as this study has shown in the context of the hinterland Malay Muslim in West Kalimantan. The existence of Islam with a good local tradition, which is still maintained by the hinterland Muslim community, is the evidence of the mutual influence of both. The combination of these two elements has generated a

${ }^{52}$ Ibrahim, "Tradisi dan Komunikasi."

${ }^{53}$ Interview with Uju Unui (Unui Salim) November 2009 (in Ibrahim, 2010b) 
unique pattern of religious sincerity, as expressed in the idea of Islam Nusantara. The presence of Islam does not authomatically mean the eradication of the local culture and tradition, a paradigm that accelerates the accepatance and spread of Islamic propagation (dakwah) among the hinterland communities.

Some evidence of the existence of Islamic contact and its influence on the practice of local traditions in hinterland Muslim communities can be seen from several traditions that still exist and continue to be practiced today, such as pantang larang, traditional healing, cultivation (buma) and topung tawar. The Islamic influence in these traditions can be seen in several ways. Firstly, the transformation of traditional invocation $\left(d u^{\prime} a\right.$ or lafaz) is carried out by incorporating of the Islamic elements, from inserting the word basmalah at the opening, shahadah at the end, or including part of the Qur'anic verses at either pace. Secondly, the substance of the message refers to, or has, a strong source of foundation with the teachings of Islam, both the Qur'an and Sunna. Thirdly, the pattern of change, adaptation, and the perfection of tradition in hinterland Muslim societies shows that Islam is very accommodative, open, and contextual. All these suggest the adaptive process of Islamization and a mutually enforcing of Islam and local culture, making it congruent religious-cultural structure.

\section{References}

Amin, Faizal. "Kitab Berladang: A Portrait of Hybrid Islam in West Kalimantan." Studia Islamika 20, no. 1 (2013): 59-96. Accessed December 26, 2018. http://journal.uinjkt.ac.id/ index.php/studia-islamika/article/view/349.

Azra, Azyumardi. Islam Nusantara: Jaringan Global dan Lokal. Bandung: Mizan, 2002.

Collins, James T. "Bahasa Pantang Larang di Pulau Tioman: Refleksifikasi Semasa Menuai"." Jurnal Dewan Bahasa 36 (1992): 916-933.

Darmadi, Didi. "Bung dan Bami' Ari: Budaya orang Melayu Buyan." Harian Equator, March 17, 2006. 
Dove, M.R. Swidden Agriculture in Indonesia. The Subsistence Strategies of the Kalimantan Kantu. Berlin, New York, \& Amsterdam: Mouton Publisher, 1985.

Erwin, and Andi Gidang. "Tradisi yang Membelajarkan: Mengurai Unsur-unsur Pendidikan dalam Tradisi Tepung Tawar Melayu Sambas." In Tradisi dan Komunikasi Orang Melayu, edited by Ibrahim, 205-226. Pontianak: STAIN Pontianak Press, 2010.

Fadli, Adi. Pemikiran Islam lokal: TGH. M. Shaleh Hambali Bengkel. Lombok: Penerbit Pustaka Lombok, 2016.

Hermansyah. "Alam orang Melayu: Kajian Ilmu di Embau

Kalimantan Barat Indonesia." Ph.D Dissertation, ATMA, Universiti Kebangsaan Malaysia, 2005.

- - - Ilmu Ghaib di Kalimantan Barat. Jakarta: Kepustakaan Populer Gramedia, 2010.

- - - " "Islam dan Budaya Lokal (Islamisasi Budaya Masyarakat

Pedalaman Kalimantan Barat)." In Dakwah Islam di Kalimantan Barat, by Yusriadi and Patmawati. Pontianak: STAIN Pontianak Press, 2006.

- - - "Islam Orang Embau." In Islam dan Etnisitas di Kalimantan Barat, edited by Yusriadi and Ambaryani. Pontianak: STAIN Pontianak Press, 2008.

Ibrahim. Hidup dan Komunikasi. Pontianak: STAIN Pontianak Press, 2010.

- - - "Hubungan Penutur Bahasa-bahasa Melayik: kes suku Iban dan Melayu di Badau, Pulau Borneo." Ph.D Dissertation, ATMA, Universiti Kebangsaan Malaysia, 2013.

- - - "Islam and Tradition in Nanga Jajang: Social and Religious Practices Of the Malay Community." Al-Albab 4, no. 2 (December 1, 2015): 217-229. Accessed December 26, 2018. http://jurnaliainpontianak.or.id/index.php/alalbab/article/view $/ 290$.

- - - Islam dan Tradisi di Nanga Jajang. Research Report of Competitive Individual lecture. Pontianak: IAIN Pontianak, 2010.

- - . "Kearifan dalam Tradisi Buma." In Kearifan Lokal dalam Pemeliharaan Alam. Kalimantan Barat: Fleghty, and PSBMB Kalimantan Barat, 2008. 
- - - "Pantang Larang dan Pengajaran Keseimbangan Hidup." In Prosiding Koloqium Internasional Khazanah Pendidikan di Alam Melayu, 55-76. Pontianak: STAIN Pontianak Press, 2014.

- - - "Tradisi dan Komunikasi: Studi atas Prosesi Topung Tawar pada Masyarakat Melayu Nanga Jajang." In Tradisi dan Komunikasi Orang Melayu, edited by Ibrahim. Pontianak: STAIN Pontianak Press, 2010.

Ibrahim, Yusriadi, and Zaenuddin. Kearifan Komunikasi dalam Pantang Larang Melayu Nanga Jajang, Kapuas Hulu. Research Report of Competitive Group. Pontianak: IAIN Pontianak, 2009.

- - - Pantang Larang Melayu Kalimantan Barat. Pontianak: STAIN Pontianak Press, and Malay Corner, 2012.

Khusen, Moh. "Contending Identity In The Islamic Ritual: The Slametan among Surinamese Javanese Muslims in The Netherlands." Al-Jami'ah: Journal of Islamic Studies 43, no. 2 (November 30, 2005): 283-308. Accessed December 26, 2018. http://www.aljamiah.or.id/index.php/AJIS/article/view/42.

King, Victor T. The People of Borneo. Oxford: Blackwell Publishers, 1993.

Muhaimin, Abdul Ghafur. "The Islamic Traditions of Cirebon." Ph.D Dissertation, Australian National University, 2006.

Qurtuby, Sumanto Al. "Southeast Asia: History, Modernity and Relegious Change." Al-Albab 2, no. 2 (November 27, 2015): 145-168. Accessed December 26, 2018. http://jurnaliain pontianak.or.id/index.php/alalbab/article/view/33.

Saparudin, Saparudin. "Salafism, State Recognition and Local Tension: New Trends in Islamic Education in Lombok." Ulumuna 21, no. 1 (June 30, 2017): 81-107. Accessed December 26, 2018. https://ulumuna.or.id/index.php/ujis/article/view/68.

Shihab, M. Quraish. Tafsir Al-Misbah. Vol. 1. Jakarta: Lentera Hati, 2004.

Sila, Muhammad Adlin. "Menjadi Muslim di Bima Sumbawa Indonesia: Keanekaragaman Politik dan Budaya." Doctoral Thesis, Australian National University, 2014. 
300 Ulumuñ, Vol. 22, No. 2 (2018)

Siradj, Said Aqiel. Islam Sumber Inspirasi Budaya Nusantara: Menuju Masyarakat Mutamaddun. Edited by A. Khoirul Anam. Jakarta Pusat: LTN NU, 2015.

Wadley, Reed L. "Circular Labor Migrations and Subsistence Agriculture: A Case of The Iban in West Kalimantan, Indonesia." Ph.D Dissertation, Arizona State University, 1997. 